\title{
PENGARUH STATUS SOSIAL EKONOMI TERHADAP MINAT BERWIRAUSAHA DI DESA JURUREJO KECAMATAN NGAWI KABUPATEN NGAWI
}

\author{
Rino Gumelar \\ Mahasiswa Prodi Ekonomi IKIP PGRI MADIUN
}

\begin{abstract}
Abstrak: Tujuan dari penelitian ini adalah: 1) menentukan status sosial ekonomi di Desa Jururejo, Ngawi, 2) menentukan minat berwirausaha di desa Jururejo, Ngawi, 3) menentukan adakah pengaruh status sosial ekonomi dari minat berwirausaha di Desa Jururejo, Ngawi. Penelitian ini menggunakan simple random sampling dari 60 orang. Pengumpulan data menggunakan kuesioner. Dalam menganalisis data digunakan korelasi produk moment metode statistik untuk menguji apakah instrumen valid dan digunakan untuk uji regresi meneliti hipotesis yang diajukan dalam penelitian ini. Hasil penelitian menunjukkan bahwa status sosial ekonomi memiliki hubungan efek positif terhadap minat berwirausaha di Desa Jururejo, Ngawi. Ini berarti bahwa nilai $r_{\text {hitung }} \geq r_{\text {tabel }}(0,490 \geq 0,254)$ atau $\operatorname{Sig}_{\text {hit }} \leq \operatorname{Sig}_{\text {prob }}(0,000 \leq 0,05)$ berarti penolakan $H_{0}$ yang menunjukkan bahwa status sosial ekonomi memiliki hubungan dengan minat berwirausaha di Desa Jururejo, Ngawi. Hasil tes lebih lanjut juga diperoleh nilai Fisher, $\mathrm{F}$ adalah 18.356 sedangkan nilai $\mathrm{F}_{\text {tabel }} 4,007$ di sisi lain adalah $\operatorname{Sig}_{\text {hit }} 0,000$ sementara besarnya $\operatorname{Sig}_{\text {hit }} 0,05$. Ini berarti bahwa nilai $F_{\text {hitung }} \geq F_{\text {tabel }}(18,356 \geq$ $4,007)$ atau $\operatorname{Sig}_{\text {hit }} \leq \operatorname{Sig}_{\text {prob }}(0,000 \leq 0,05)$ berarti penolakan $\mathrm{H}_{0}$ yang menunjukkan bahwa ada status ekonomi sosial yang signifikan dari minat berwirausaha di Desa Ngawi Jururejo. Juga diperoleh hasil uji t, nilai $t$ adalah 4,284 sedangkan $t_{\text {tabel }}$ 1,672 di sisi lain nilai $\operatorname{Sig}_{\text {hit }}$ adalah 0,000 sedangkan $\operatorname{Sig}_{\text {prob }}$ 0,05. Ini berarti bahwa nilai $t_{\text {hitung }} \geq t_{\text {tabel }}(4,284 \geq 1,672)$ atau $\operatorname{Sig}_{\text {hit }} \leq$ $\operatorname{Sig}_{\text {prob }}(0,000 \leq 0,05)$ berarti penolakan $\mathrm{H}_{0}$ yang menunjukkan bahwa ada yang berbeda sosial ekonomi status pengaruh minat berwirausaha di Desa Jururejo. Hasil $\mathrm{R}_{2}$ dari 0,240 menunjukkan bahwa $24 \%$ variabel minat berwirausaha dipengaruhi oleh status ekonomi sosial, sedangkan sisanya $76 \%$ dipengaruhi oleh faktor lain.
\end{abstract}

Keywords: Status Ekonomi Sosial, minat berwirausaha

\section{PENDAHULUAN}

Indonesia merupakan Negara yang berdasarkan perkembangan ekonominya dikategorikan sebagai Negara berkembang. Saat ini Indonesia sedang berusaha menjadi negara yang maju. Untuk menjadi negara yang maju, Indonesia harus meningkatkan perekonomian di segala sektor. Dimana sektor yang dikembangkan harus bisa menciptakan kesejahteraan rakyat serta memberikan kesan positif baik di dalam negeri, regional, maupun internasional. Dalam pembangunan nasional ada kendala yang belum bisa terselesaikan, khususnya masalah ketenagakerjaan. Masalah ketenaga kerjaan di Indonesia sangatlah kompleks.

Masalah pengangguran menimbulkan dampak-dampak baru yang akan muncul seperti kemiskinan, kebodohan, dan juga gangguan keamanan. Untuk mengurangi masalah pengangguran di Indonesia, setiap orang tidak hanya berdiam diri dan mengandalkan pekerjaan yang disediakan pemerintah tetapi juga harus bisa menciptakan lapangan pekerjaan. Maka berwirausaha dan menjadi pelaku usaha merupakan pilihan yang positif untuk menciptakan lapangan pekerjaan sendiri.

Jumlah wirausaha di Indonesia masih sangat sedikit. Suatu pernyataan yang ber- 
sumber dari PBB menyatakan bahwa: Suatu negara akan mampu membangun apabila memiliki wirausahawan sebanyak $2 \%$ dari jumlah penduduknya. Jadi, jika negara kita berpenduduk 200 juta jiwa, maka wirausahawannya harus lebih kurang sebanyak 4 juta. Katakanlah jika kita hitung semua wirausahawan Indonesia mulai dari pedagang kecil sampai perusahaan besar ada sebanyak 3 juta, tentu bagian besarnya adalah kelompok kecilkecil yang belum terjamin mutunya dan belum terjamin kelangsungan hidupnya (kontinuitasnya). Keberhasilan pembangunan yang dicapai oleh negara Jepang ternyata disponsori oleh wirausahawan yang telah berjumlah 2\% tingkat sedang, berwirausahawan kecil sebanyak $20 \%$ dari jumlah penduduknya. Inilah kunci keberhasilan pembangunan negara Jepang. Heidjrachman Ranu (dalam Buchari Alma, 2005:5).

Kegiatan berwirausaha merupakan salah satu kegiatan yang sangat penting, karena dengan berwirausaha masyarakat tidak perlu mengandalkan lapangan pekerjaan yang ditawarkan yang mana lapangan pekerjaan tersebut semakin banyak saingannya akan semakin sempit peluang kerjanya. Dari kegiatan berwirausaha ini masyarakat dapat berpartisipasi mengembangkan perekonomian negara dan juga meningkatkan status sosial ekonomi.

Kegiatan berwirausaha merupakan salah satu kegiatan yang sangat penting, karena dengan berwirausaha masyarakat tidak perlu mengandalkan lapangan pekerjaan yang ditawarkan yang mana lapangan pekerjaan tersebut semakin banyak saingannya akan semakin sempit peluang kerjanya. Dengan melakukan kegiatan berwirausaha, masyarakat tidak perlu tergantung kepada orang lain, mereka dituntut agar mempunyai pola pikir yang mandiri, bekerja untuk dirinya sendiri bukan orang lain. Dari kegiatan berwirausaha ini masyarakat dapat berpartisipasi mengembangkan perekonomian negara dan juga meningkatkan status sosial ekonomi.
Status sosial dalam ilmu sosiologi sering disebut dengan istilah kelas sosial. Status sosial ekonomi terkandung unsur pendidikan, pekerjaan, penghasilan, kekayaan/kepemilikan barang, kehormatan atau kedudukan seseorang dalam suatu masyarakat. Minat seseorang untuk berwira usaha bukan dipengaruhi karena tidak adanya kreatifitas tetapi juga dipengaruhi faktor status sosial ekonomi yang mana bisa mempengaruhi minat seseorang untuk berwira usaha.

Minat seseorang mulai muncul karena adanya keinginan dan dorongan dari lingkungan, baik dari lingkungan keluarga maupun lingkungan masyarakat. Begitu juga dengan minat berwirausaha, tidak hanya muncul dari keinginan dan dorongan, pengalaman yang pernah didapat tentang berwira usaha juga memacu seseorang untuk melakukan kegiatan wirausaha.

Soerjono Soekanto (2012:210) berpendapat bahwa "kedudukan (status) diartikan sebagai tempat atau posisi seseorang dalam suatu kelompok sosial".

Menurut Nugroho J. Setiadi (2003: 304) "kedudukan (status) diartikan sebagai tempat atau posisi seseorang dalam kelompok sosial". Secara abstrak, kedudukan berarti tempat seseorang dalam suatu pola tertentu.

Menurut Soekanto (dalam Dadang Supardan, 2012:27) bahwa "Istilah sosial pada ilmu sosial menunjukkan pada objeknya, yaitu masyarakat". Sedangkan istilah pada Departemen Sosial, "Kegiatan-kegiatan yang ditujukan untuk mengatasi persoalanpersoalan yang dihadapi masyarakat dalam bidang kesejahteraan, seperti tuna karya, tuna susila, tuna wisma, orang jompo, anak yatim piatu, dan lain sebagainya, yang ruang lingkupnya adalah pekerjaan ataupun kesejahteraan sosial".

Menurut Soekanto (dalam Dadang Supardan, 2007:27) mengemukakan bahwa, "Istilah sosial pun berkenaan dengan perilaku interpersonal atau yang berkaitan dengan proses-proses sosial". 
Menurut Sastradipoera (dalam Dadang Supardan, 2007:366), "Istilah ekonomi berasal dari bahasa Yunani yaitu oikosnamos atau oikonomia yang artinya manajemen urusan rumah tangga, khususnya penyediaan dan administrasi pendapatan".

Menurut Samuelson dan Nordhanus (dalam Dadang Supardan, 2007:367) berpendapat, "Ilmu ekonomi adalah studi tentang perilaku orang dan masyarakat dalam memilih cara menggunakan sumber daya yang langka dan memiliki beberapa alternatif penggunaan dalam rangka memproduksi berbagai komoditi, kemudian menyalurkannya baik saat ini maupun di masa depan kepada berbagai individu dan kelompok yang ada dalam suatu masyarakat".

"Status sosial ekonomi seseorang di dalam masyarakat secara kelompok membentuk sistem kelas sosial, yakni kelompokkelompok masyarakat yang terbentuk berdasarkan perbedaan dan persamaan secara relatif atas sikap, nilai dan gaya hidup" (Mulyadi Nitisusastro, 2009:127).

Menurut Burhan Bungin (2006:49), "Strata sosial di masyarakat melahirkan kelas-kelas sosial yang terdiri dari tiga tingkatan, yaitu atas (Upper Class), menengah (Middle Class), dan bawah (Lower Class)". Kelas atas mewakili kelompok elite di masyarakat yang jumlahnya sangat terbatas. Kelas menengah mewakili kelompok professional, kelompok pekerja, wiraswastawan, pedagang, dan kelompok fungsional lainnya.

Menurut Leon dan Leslie (2004:332), Pendekatan yang sistematis untuk mengukur kelas sosial tercakup dalam berbagai kategori yang luas berikut ini: ukuran subyektif, ukuran reputasi, dan ukuran obyektif dari kelas sosial.

1) Ukuran Subyektif

Dalam pendekatan subyektif untuk mengukur kelas sosial, para individu diminta menaksir kedudukan kelas sosial mereka masing-masing.

2) Ukuran Reputasi

Pendekatan reputasi untuk mengukur kelas sosial memerlukan informan mengenai masyarakat yang dipilih untuk membuat pertimbangan awal mengenai keanggotaan kelas sosial orang lain dalam masyarakat.

3) Ukuran obyektif

Berbeda dengan metode subyektif dan reputasi, yang mengharuskan orang memimpikan kedudukan kelas mereka sendiri atau kedudukan para anggota masyarakat lainnya, ukuran subyektif terdiri dari berbagai variabel demografis atau sosio ekonomi yang dipilih mengenai (para) individu yang sedang dipelajari. Ketika memilih ukuran obyektif kelas sosial, kebanyakan peneliti lebih menyukai satu atau beberapa variabel berikut: pekerjaan, jumlah penghasilan, dan pendidikan.

Menurut Soerjono Soekanto (2012: 209), ukuran atau kriteria yang biasa dipakai untuk menggolong-golongkan anggotaanggota masyarakat ke dalam suatu lapisan adalah sebagai berikut:

1) Ukuran kekayaan

Barang siapa yang memiliki kekayaan paling banyak termasuk dalam lapisan teratas.

2) Ukuran kekuasaan

Barang siapa yang memiliki kekuasaan atau yang mempunyai wewenang terbesar menempati lapisan atasan.

3) Ukuran kehormatan

Ukuran kehormatan tersebut mungkin terlepas dari ukuran-ukuran kekayaan dan/atau kekuasaan. Orang yang paling disegani dan dihormati, mendapat tempat yang teratas. Ukuran semacam ini, banyak dijumpai pada masyarakat-masyarakat tradisional.

4) Ukuran ilmu pengetahuan

Ilmu pengetahuan sebagai ukuran dipakai oleh masyarakat yang menghargai ilmu pengetahuan. Akan tetapi, ukuran tersebut kadang-kadang menyebabkan terjadinya 
akibat-akibat yang negatif karena ternyata bukan mutu ilmu pengetahuan yang dijadikan ukuran, tetapi gelar kesarjanaannya.

Menurut Yudrik Jahja (2011:63) "Minat ialah suatu dorongan yang menyebabkan terikatnya perhatian individu pada objek tertentu seperti pekerjaan, pelajaran, benda, dan orang".

Menurut Elizabeth B. Hurlock (2003: 114) "Minat merupakan sumber motivasi yang mendorong orang untuk melakukan apa yang mereka inginkan bila mereka bebas memilih".

"Minat berhubungan dengan sesuatu yang menguntungkan dan dapat menimbulkan kepuasan bagi dirinya. Kesenangan merupakan minat yang sifatnya sementara. Adapun minat yang bersifat tetap (persistent) dan ada unsur memenuhi kebutuhan dan memberikan kepuasan. Semakin sering minat diekspresikan dalam kegiatan akan semakin kuat minat tersebut, sebaliknya minat akan menjadi pupus kalau tidak ada kesempatan untuk mengekspresikannya" (Yudrik Jahja, 2011:63).

Yudrik Jahja (2011:63) berpendapat bahwa minat memiliki sifat dan karakter khusus, sebagai berikut:

1) Minat bersifat pribadi (individual), ada perbedaan antara minat seseorang dan orang lain.

2) Minat menimbulkan efek diskriminatif.

3) Erat hubungannya dengan motivasi, mempengaruhi dan dipengaruhi motivasi.

Crow \& Crow (dalam Yuwono dkk, 2008:1) menyebutkan bahwa ada tiga aspek dalam diri seseorang, yaitu:

1) Dorongan dari dalam untuk memenuhi kebutuhan diri sebagai sumber penggerak untuk melakukan sesuatu.

2) Kebutuhan untuk berhubungan dengan lingkungan sosialnya yang akan menentukan posisi individu dalam lingkungannya.

3) Perasaan individu terhadap suatu pekerjaan yang dilakukannya.

Menurut Schumpeter (dalam Buchari Alma, 2005:22) "Entreprenuer atau wira- usaha adalah orang yang mendobrak sistem ekonomi yang ada dengan memperkenalkan barang dan jasa yang baru, dengan menciptakan bentuk organisasi baru atau mengolah bahan baku baru."

Menurut Sri Edi Swasono (dalam Suryana, 2001:5) dalam konteks bisnis, "wirausaha adalah pengusaha, tetapi tidak semua pengusaha adalah wirausaha. Wirausaha adalah pionir dalam bisnis, innovator, penanggung resiko, yang mempunyai penglihatan/visi ke depan, dan memilih keunggulan dalam berprestasi di bidang usaha."

Menurut Skinner (dalam Pandji Anoraga dan Djoko Sudantoko, 2002:138) "wirausaha (entrepreneur) merupakan seseorang yang mengambil risiko yang diperlukan untuk mengorganisasikan dan mengolah suatu bisnis dan menerima imbalan/balas jasa berupa profit finansial dan maupun non finansial."

Menurut Maslow (dalam Suryana, 2001:27) "kebutuhan itu bertingkat sesuai dengan tingkatan pemuasannya, yaitu kebutuhan phisiologis (physiological needs), kebutuhan akan keamanan (security needs), kebutuhan sosial (social needs), kebutuhan harga diri (estee needs), dan kebutuhan akan aktualisasi diri (selfactualization needs)".

Menurut Yuyun Wirasasmita (dalam Suryana, 2001:29) berpendapat beberapa alasan mengapa seseorang berwirausaha, yakni:

1) Alasan keuangan, yaitu untuk mencari nafkah, untuk menjadi kaya, untuk mencari pendapatan tambahan, sebagai jaminan stabilitas keuangan.

2) Alasan sosial, yaitu untuk memperoleh gengsi/status, untuk dapat dikenal dan dihormati, untuk menjadi contoh bagi orang tua di desa, agar dapat bertemu dengan orang banyak.

3) Alasan pelayanan, untuk memberi pekerjaan pada masyarakat, untuk menatar masyarakat, untuk membantu ekonomi masyarakat, demi masa depan anak-anak 
dan keluarga, untuk mendapatkan kesetiaan suami/isteri, untuk membahagiakan ayah dan ibu.

4) Alasan memenuhi diri, yaitu untuk menjadi atasan/mandiri, untuk mencapai sesuatu yang diinginkan, untuk menghindari ketergantungan pada orang lain, agar lebih produktif, dan untuk menggunakan kemampuan pribadi.

Buchari Alma (2005: 1) berpendapat bahwa wirausaha merupakan potensi pembangunan, baik dalam jumlah maupun dalam mutu wirausaha itu sendiri. Sekarang ini jumlah wirausahawan Indonesia masih sedikit dan mutunya belum bisa dikatakan hebat, sehingga persoalan pembangunan wirausaha Indonesia merupakan persoalan mendesak bagi suksesnya pembangunan. Jika diperhatikan manfaat adanya wirausaha banyak sekali. Lebih rinci manfaatnya antara lain:

1) Menambah daya tampung tenaga kerja, sehingga dapat mengurangi pengangguran.

2) Sebagai generator pembangunan lingkungan, bidang produksi, distribusi, pemeliharaan lingkungan, kesejahteraan, dan sebagainya.

3) Menjadi contoh bagi anggota masyarakat lain, sebagai pribadi tunggal yang patut dicontoh, diteladani, karena seorang wirausaha itu adalah orang terpuji, jujur, berani, hidup tidak merugikan orang lain.

4) Selalu menghormati hukum dan peraturan yang berlaku, berusaha selalu menjaga dan membangun lingkungan.

5) Berusaha memberi bantuan kepada orang lain dan pembangunan sosial, sesuai dengan kemampuannya.

6) Berusaha mendidik karyawannya menjadi orang mandiri, disiplin, jujur, tekun dalam menghadapi pekerjaan.

7) Memberi contoh bagaimana kita harus bekerja keras, tetapi tidak melupakan perintah-perintah agama.

8) Hidup secara efisien, tidak berfoya-foya dan tidak boros.
9) Memelihara keserasian lingkungan, baik dalam pergaulan maupun kebersihan lingkungan.

Geoffrey G. Meredith (dalam Suryana, 2001:15) bahwa ciri-ciri dari kewirausahaan adalah:

\section{1) Percaya Diri (self-confidence)}

Kepercayaan diri merupakan suatu panduan sikap dan keyakinan seseorang dalam menghadapi tugas atau pekerjaan, menurut Soesarsono Wijandi. Dalam praktik sikap dan kepercayaan ini merupakan sikap dan keyakinan untuk memulai, melakukan dan menyelesaikan suatu tugas atau pekerjaan yang dihadapi.

Kepercayaan diri ini bersifat internal pribadi seseorang yang sangat relatif dan dinamis, dan banyak ditentukan oleh kemampuannya untuk memulai, melaksanakan, dan menyelesaikan suatu pekerjaan. Orang yang percaya diri memiliki kemampuan untuk menyelesaikan pekerjaan dengan sistematis, berencana, efektif, dan efisien. Kepercayaan diri juga selalu ditunjukkan oleh ketenangan, ketekunan, kegairahan, dan kemantapan dalam melakukan pekerjaan.

Keberanian yang tinggi dalam mengambil resiko dan perhitungan yang matang dibarengi dengan optimisme harus disesuaikan dengan kepercayaan diri. Oleh sebab itu, optimisme dan keberanian mengambil resiko dalam menghadapi suatu tantangan dipengaruhi oleh kepercayaan diri. Kepercayaan diri juga ditentukan oleh kemandirian dan kemampuan sendiri. Seseorang yang memiliki kepercayaan diri yang tinggi, relatif lebih mampu menghadapi dan menyelesaikan masalah sendiri tanpa menunggu bantuan orang lain.

\section{2) Orientasi Tugas dan Hasil}

Seseorang yang selalu mengutamakan tugas dan hasil adalah orang yang selalu mengutamakan nilai-nilai motif berprestasi, berorientasi pada laba, 
ketekunan dan ketabahan, tekad kerja keras, mempunyai dorongan kuat, energik, dan berinisiatif. Berinisiatif artinya selalu ingin mencari dan memulai. Untuk memulai diperlukan niat dan tekad yang kuat, serta karsa yang kuat. Sekali sukses atau berprestasi, maka sukses berikutnya akan menyusul, sehingga usahanya semakin maju dan semakin berkembang. Dalam berwirausaha, peluang hanya diperoleh apabila ada inisiatif. Perilaku inisiatif ini biasanya diperoleh melalui pelatihan dan pengalaman yang bertahuntahun, dan pengembangannya diperoleh dengan cara disiplin diri, berpikir kritis, tanggap, bergairah, dan semangat berprestasi.

\section{3) Keberanian Mengambil Resiko}

Kemauan dan kemampuan untuk mengambil resiko merupakan salah satu nilai utama dalam kewirausahaan. Wirausaha yang tidak mau mengambil resiko akan sukar memulai atau berinisiatif. Seorang wirausaha kurang menyukai resiko yang terlalu rendah atau yang terlalu tinggi. Resiko yang terlalu rendah akan memperoleh sukses yang relatif rendah. Sebaliknya, resiko yang tinggi kemungkinan memperoleh sukses yang tinggi, tetapi kegagalan yang sangat tinggi. Oleh sebab itu, seseorang akan lebih menyukai resiko yang paling seimbang (moderat). Dengan demikian, keberanian untuk menanggung resiko yang menjadi nilai kewirausahaan adalah pengambilan resiko yang penuh dengan perhitungan dan realistik. Kepuasan yang besar diperoleh apabila berhasil dalam melaksanakan tugas-tugasnya secara realistik.

\section{4) Kepemimpinan}

Seorang wirausaha yang berhasil selalu memiliki sifat kepemimpinan, kepeloporan, keteladanan. Selalu ingin tampil beda, lebih dulu, lebih menonjol. Dengan menggunakan kemampuan kreatifitas dan keinovasiannya, wirausahawan selalu menampilkan barang dan jasa-jasa yang dihasilkan dengan lebih cepat, lebih dulu dan segera berada di pasar.

Wirausahawan selalu menampilkan produk dan jasa-jasa baru dan berbeda sehingga menjadi pelopor baik dalam proses produksi maupun pemasarannya. Wirausahawan selalu memanfaatkan perbedaan sebagai suatu yang menambah nilai. Karena itu perbedaan bagi seseorang yang memiliki jiwa kewirausahaan merupakan sumber pembaharuan untuk menciptakan nilai.

\section{5) Berorientasi Ke Masa Depan}

Orang yang berorientasi ke masa depan adalah orang yang memiliki perspektif dan pandangan ke masa depan. Karena itu mereka memiliki pandangan yang jauh ke masa depan, maka selalu berusaha untuk berkarsa dan berkarya. Kuncinya pada kemampuan untuk menciptakan sesuatu yang baru dan berbeda dengan yang sudah ada sekarang. Meskipun dengan resiko yang mungkin terjadi, ia tetap tabah untuk mencari peluang dan tantangan demi pembaharuan masa depan. Pandangan yang jauh ke depan, membuat wirausaha tidak cepat puas dengan karsa dan karya yang sudah ada sekarang. Oleh sebab itu, ia selalu mempersiapkannya dengan mencari suatu peluang.

6) Keorisinilan : Kreativitas dan Keinovasian

Nilai inovatif, kreatif dan fleksibel merupakan unsur-unsur keorisinilan seseorang. Wirausaha yang inovatifadalah orang yang kreatif dan yakin dengan adanya cara-cara baru yang lebih baik. Yuyun Wirasasmita (dalam Suryana, 2001: 17) ciri-cirinya, bahwa:

a) Tidak pernah puas dengan cara-cara yang dilakukan saat ini, meskipun cara tersebut cukup baik.

b) Selalu menuangkan imajinasi dalam pekerjaannya. 
c) Selalu ingin tampil berbeda atau selalu memanfaatkan perbedaan.

Suryana (2001:35) berpendapat bahwa kewirausahaan berkembang dan diawali dengan adanya inovasi. Inovasi yang dipengaruhi oleh faktor pribadi, lingkungan, dan sosiologi.

\section{1) Faktor pribadi}

Faktor pribadi atau individu yang memicu kewirausahaan adalah pencapaian locus of control, toleransi, pengambilan resiko, nilai-nilai pribadi, pendidikan, pengalaman, usia, komitmen, dan ketidakpuasan.

\section{2) Faktor Lingkungan}

Faktor pemicu yang berasal dari lingkungan ialah peluang, model peran, aktivitas, pesaing, inkubator, sumber daya, dan kebijakan pemerintah.

\section{3) Faktor Sosiologi}

Faktor pemicu yang berasal dari lingkungan sosial atau sosiologi meliputi asal keluarga, orang tua, jaringan kelompok yang sangat menentukan kewirausahaan.

Geoffrey G. Meredith (dalam Suryana, 2001:8) mengemukakan delapan karakteristik, yaitu meliputi:

1) Desire for Responsibility, yaitu memiliki rasa tanggung jawab atas usaha-usaha yang dilakukannya. Seseorang yang memiliki rasa tanggung jawab akan selalu mawas diri.

2) Preference for moderate risk, yaitu lebih memilih resiko yang moderat, artinya ia selalu menghindari resiko yang rendah dan menghindari resiko yang tinggi.

3) Confidence in their ability to success, yaitu percaya akan kemampuan dirinya untuk berhasil.

4) Desire for immediate feedback, yaitu selalu menghendaki umpan balik yang segera.

5) High level for energy, yaitu memiliki semangat dan kerja keras untuk mewujud- kan keinginannya demi masa depan yang lebih baik.

6) Future orientation, yaitu berorientasi ke masa depan, perspektif, dan berwawasan jauh ke depan.

7) Skill at organizing, yaitu memiliki keterampilan dalam mengorganisasikan sumber daya untuk menciptakan nilai tambah.

8) Value of achievement over money, yaitu selalu menilai prestasi dengan uang.

\section{Metodologi Penelitian}

Tempat penelitian tidak lain adalah tempat dimana proses studi yang digunakan untuk memperoleh pemecahan masalah penelitian berlangsung (Sukardi, 2003:53). Penelitian dilakukan di Desa Jururejo yang berlokasi di Kecamatan Ngawi Kabupaten Ngawi.

Rancangan penelitian yang digunakan dalam penelitian ini adalah penelitian deskriptif (descriptive research). "Penelitian deskriptif ditujukan untuk mendeskripsikan atau menggambarkan fenomena-fenomena yang ada, baik fenomena yang bersifat alamiah ataupun rekayasa manusia" (Nana Syaodih, 2005:72).

Menurut Sugiyono (2010:61), "variabel bebas merupakan variabel yang mempengaruhi atau yang menjadi sebab perubahannya atau timbulnya variabel dependen (terikat)". Dalam penelitian ini variabel bebasnya adalah status sosial ekonomi. Dalam penelitian ini variabel terikatnya adalah minat berwirausaha. Metode yang akan digunakan dalam penelitian ini adalah deskriptif kuantitatif'.

"Populasi pada prinsipnya adalah semua anggota kelompok manusia, binatang, peristiwa, atau benda yang tinggal bersama dalam satu tempat dan secara terencana menjadi target kesimpulan dari hasil akhir suatu penelitian" (Sukardi, 2003:53). Populasi dalam penelitian ini adalah seluruh warga Desa Jururejo Kecamatan Ngawi Kabupaten Ngawi. 
"Sampel adalah sebagian dari jumlah populasi yang dipilih untuk sumber data tersebut" (Sukardi, 2003:54). Sampel dari penelitian ini adalah 60 warga di Desa Jururejo Kecamatan Ngawi Kabupaten Ngawi.

"Teknik yang digunakan adalah teknik Simple Random Sampling yang mana seluruh individu yang menjadi anggota populasi memiliki peluang yang sama dan bebas dipilih sebagai anggota sampel" (Nana Syaodih, 2012:255).

Teknik pengumpulan data yang digunakan adalah sebagai berikut: MetodeKuisioner (Angket). Menurut Sugiyono (2009:199), "kuesioner merupakan teknik pengumpulan data yang dilakukan dengan cara memberi seperangkat pertanyaan atau pernyataan tertulis kepada responden untuk dijawabnya". Metode kuisioner digunakan untuk mengumpulkan data mengenai status sosial ekonomi dan minat berwirausaha.

\section{Hasil Penelitian}

Deskriptif variabel status sosial ekonomi dengan jumlah data $(\mathrm{N})$ sebanyak 60 warga bahwa hasil kuisioner yang diperoleh nilai rata-rata $\geq 56,22$ sebanyak 47 warga atau $78 \%$, sedangkan yang berada di bawah ratarata 13 warga atau $22 \%$. Berdasarkan hasil analisis deskripsi data sebagai berikut: (a) jumlah skor total sebesar 3373; (b) nilai ratarata hitung (mean) sebesar 56,22; (c) median sebesar 57,00; (d) modus sebesar 57; (e) standar deviasi sebesar 6,702; (f) nilai minimum sebesar 40; (g) nilai maximum sebesar 68. Jadi status sosial ekonomi di Desa Jururejo Kecamatan Ngawi Kabupaten Ngawi baik karena di atas 50\% sebesar 78\%.

Deskriptif variabel minat berwirausaha dengan jumlah data $(\mathrm{N})$ sebanyak 60 warga bahwa hasil kuisioner yang diperoleh nilai hasil rata-rata $\geq 55,52$ sebanyak 38 warga atau $63 \%$, sedangkan yang berada di bawah ratarata sebanyak 22 warga atau $37 \%$. Berdasarkan hasil analisis deskripsi data sebagai berikut: (a) jumlah skor total sebesar 3331; (b) nilai rata-rata hitung (mean) sebesar 55,52; (c) median sebesar 56,50; (d) modus sebesar 52; (e) standar deviasi sebesar 6,990; (f) nilai minimum sebesar 44; (g) nilai maximum sebesar 73. Jadi minat berwirausaha di Desa Jururejo Kecamatan Ngawi Kabupaten Ngawi baik karena di atas 50\% sebesar 63\%.

\section{Uji Hipotesis}

1. Uji Korelasi

Uji korelasi digunakan untuk mencari keeratan hubungan antara status sosial ekonomi dengan minat berwirausaha. Besarnya nilai $\mathrm{r}_{\text {hit }}$ adalah 0,490 sedangkan $\mathrm{r}_{\text {tab }} 0,254$, di ain pihak besarnya $\operatorname{Sig}_{\text {hit }}$ adalah 0,000 sedangkan $\operatorname{Sig}_{\text {prob }} 0,05$. Hal ini berarti bahwa nilai $r_{\text {hit }} \geq r_{\text {tab }}(0,490 \geq 0,254)$ atau $\operatorname{Sig}_{\text {hit }} \leq \operatorname{Sig}_{\text {prob }}(0,000 \leq 0,05)$. Atas dasar uji korelasi tersebut dapat disimpulkan bahwa $\mathrm{H}_{0}$ ditolak, artinya ada hubungan minat berwirausaha dengan minat berwirausaha di Desa Jururejo Kecamatan Ngawi Kabupaten Ngawi. Dalam uji determinasi yang diperoleh nilai $\mathrm{R}^{2}$ ( $\mathrm{R}$ Square) atau koefisien determinasi yang digunakan untuk mengetahui seberapa besar prosentase sumbangan status sosial ekonomi terhadap minat berwirausaha. Nilai $\mathrm{R}^{2}$ adalah 0,240. Jadi sumbangan pengaruh dari status sosial ekonomi terhadap minat berwirausaha yaitu $24 \%$ sedangkan sisanya sebesar $76 \%$ dipengaruhi oleh faktor lain.

2. Uji Fisher

Diketahui bahwa besarnya nilai $F_{\text {hitung }}$ adalah 18,356 sedangkan $F_{\text {tabel }}$ sebesar 4,007, di lain pihak besarnya $\mathrm{Sig}_{\text {hit }}$ adalah 0,000 sedangkan $\operatorname{Sig}_{\text {prob }} 0,05$. Hal ini berarti bahwa nilai $\mathrm{F}_{\text {hitung }} \geq \mathrm{F}_{\text {tabel }}(18,356 \geq 4,007)$ atau $\operatorname{Sig}_{\text {hit }} \leq \operatorname{Sig}_{\text {prob }}(0,000 \leq 0,05)$. Atas dasar uji Fisher tersebut dapat disimpulkan $\mathrm{H}_{0}$ ditolak, artinya berarti ada pengaruh status sosial ekonomi terhadap minat berwirausaha di Desa Jururejo Kecamatan Ngawi Kabupaten Ngawi. Uji Fisher atau 
Anova ini juga digunakan untuk uji linearitas. Karena $F_{\text {hitung }} \geq \mathrm{F}_{\text {tabel }}(18,356 \geq$ 4,007), maka dapat berarti ada pengaruh status sosial ekonomi terhadap minat berwirausaha di Desa Jururejo Kecamatan Ngawi Kabupaten Ngawi.

3. Ujit

Dapat dibuat persamaan garis regresi sebagai berikut: $\mathrm{Y}=26,768+0,511 \mathrm{X}$, artinya adalah apabila status sosial ekonomi meningkat satu kali maka minat berwirausaha akan mengalami kenaikan sebanyak $0,511 \%$, sedangkan faktor yang lainnya tetap. Dapat diketahui bahwa nilai $\mathrm{t}_{\text {hitung }}$ adalah 4,284 sedangkan $\mathrm{tt}_{\text {abel }}$ sebesar 1,672, di lain pihak nilai $\mathrm{Sig}_{\text {hit }}$ adalah 0,000 sedangkan $\mathrm{Sig}_{\text {prob }}$ 0,05. Hal ini berarti bahwa nilai $t_{\text {hitung }} \geq t_{\text {tabel }}(4,284 \geq 1,672)$ atau $\operatorname{Sig}_{\text {hit }} \leq \operatorname{Sig}_{\text {prob }}(0,000 \leq 0,05)$. Atas dasar uji t tersebut dapat disimpulkan $\mathrm{H}_{0}$ ditolak, artinya berarti ada beda pengaruh status sosial ekonomi terhadap minat berwirausaha di Desa Jururejo Kecamatan Ngawi Kabupaten Ngawi.

\section{Simpulan}

Atas dasar hasil pengujian hipotesis dapat diambil simpulan sebagai berikut:

1) Simpulan Uji Korelasi

Hasil dari pengujian korelasi dapat diperoleh besarnya $r_{\text {hit }}$ adalah 0,490 sedangkan $\mathrm{r}_{\text {tab }}$ 0,254, di lain pihak besarnya $\mathrm{Sig}_{\text {hit }}$ adalah 0,000 sedangkan $\operatorname{Sig}_{\text {prob }}$ 0,05. Hal ini berarti bahwa nilai $r_{\text {hit }} \geq r_{\text {tab }}(0,490 \geq 0,254)$ atau $\operatorname{Sig}_{\text {hit }} \leq \operatorname{Sig}_{\text {prob }}(0,000 \leq 0,05)$. Selain itu diperoleh nilai $\mathrm{R}^{2}$ adalah 0,240 . Jadi sumbangan pengaruh dari status sosial ekonomi terhadap minat berwirausaha yaitu $24 \%$.

2) Simpulan Uji Fisher

Hasil dari pengujian Fisher dengan uji Anova dapat diperoleh nilai nilai $\mathrm{F}_{\text {hitung }}$ adalah 18,356 sedangkan $\mathrm{F}_{\text {tabel }}$ sebesar 4,007, di lain pihak besarnya Sig $_{\text {hit }}$ adalah 0,000 sedangkan $\operatorname{Sig}_{\text {prob }} 0,05$. Hal ini berarti bahwa nilai $\mathrm{F}_{\text {hitung }} \geq \mathrm{F}_{\text {tabel }}(18,356 \geq 4,007)$ atau $\operatorname{Sig}_{\text {hit }} \leq \operatorname{Sig}_{\text {prob }}(0,000 \leq 0,05)$. Sesuai hipotesis yang diajukan dapat diperoleh simpulan bahwa ada pengaruh status sosial ekonomi terhadap minat berwirausaha di Desa Jururejo Kecamatan Ngawi Kabupaten Ngawi.

3) Simpulan Ujit

Dari hasil perhitungan atau pengujian yang dilakukan diperoleh persamaan regresi sebagai berikut: $\mathrm{Y}=26,768+$ 0,511 , artinya adalah apabila status sosial ekonomi meningkat $1 \%$ maka minat berwirausaha akan mengalami kenaikan sebanyak $51,1 \%$, sedangkan faktor yang lainnya tetap.

Hasil dari uji $t$ dapat diperoleh nilai $\mathrm{t}_{\text {hitung }}$ adalah 4,284 sedangkan $\mathrm{t}_{\text {tabel }}$ sebesar 1,672, di lain pihak nilai $\operatorname{Sig}_{\text {hit }}$ adalah 0,000 sedangkan $\operatorname{Sig}_{\text {prob }} 0,05$. Hal ini berarti bahwa nilai $\mathrm{t}_{\text {hitung }} \geq \mathrm{t}_{\text {tabel }}(4,284 \geq 1,672)$ atau $\operatorname{Sig}_{\text {hit }} \leq \operatorname{Sig}_{\text {prob }}(0,000 \leq 0,05)$. Atas dasar ujit tersebut dapat disimpulkan $\mathrm{H}_{0}$ ditolak, artinya berarti ada beda pengaruh status sosial ekonomi ter-hadap minat berwirausaha di Desa Jururejo Kecamatan Ngawi Kabupaten Ngawi.

\section{Pembahasan}

Adapun pembahasan dari hasil pengujian dalam penelitian ini adalah sebagai berikut:

1. Simpulan Uji Korelasi

Hasil dari pengujian korelasi dapat diperoleh besarnya $r_{\text {hit }}$ adalah 0,490 sedangkan $\mathrm{r}_{\text {tab }}$ 0,254, di lain pihak besarnya Sig $_{\text {hit }}$ adalah 0,000 sedangkan $\operatorname{Sig}_{\text {prob }}$ 0,05. Hal ini berarti bahwa nilai $r_{\text {hit }} \geq r_{\text {tab }}(0,490 \geq 0,254)$ atau $\operatorname{Sig}_{\text {hit }}<\operatorname{Sig}_{\text {prob }}(0,000<0,05)$. Selain itu diperoleh nilai $\mathrm{R}^{2}$ adalah 0,240 . Jadi sumbangan pengaruh dari status sosial ekonomi terhadap minat berwirausaha yaitu $24 \%$. Sesuai hipotesis yang diajukan dapat diperoleh simpulan bahwa ada hubungan status sosial ekonomi terhadap 
minat berwira-usaha di Desa Jururejo Kecamatan Ngawi Kabupaten Ngawi.

\section{Simpulan Uji Fisher}

Hasil dari pengujian Fisher dengan uji Anova dapat diperoleh nilai $\mathrm{F}_{\text {hitung }}$ adalah 18,356 sedangkan $\mathrm{F}_{\text {tabel }}$ sebesar 4,007, di lain pihak besarnya Sig $_{\text {hit }}$ adalah 0,000 sedangkan $\mathrm{Sig}_{\text {prob }}$ 0,05. Hal ini berarti bahwa nilai $\mathrm{F}_{\text {hitung }} \geq \mathrm{F}_{\text {tabel }}(18,356 \geq 4,007)$ atau $\operatorname{Sig}_{\text {hit }} \leq \operatorname{Sig}_{\text {prob }}(0,000 \leq 0,05)$. Sesuai hipotesis yang diajukan dapat diperoleh simpulan bahwa ada pengaruh status sosial ekonomi terhadap minat berwirausaha di Desa Jururejo Kecamatan Ngawi Kabupaten Ngawi.

3. Simpulan Ujit

Dari hasil perhitungan atau pengujian yang dilakukan diperoleh persamaan regresi sebagai berikut: $\mathrm{Y}=26,768+$ 0,511 , artinya adalah apabila status sosial ekonomi meningkat $1 \%$ maka minat berwirausaha akan mengalami kenaikan sebanyak $51,1 \%$, sedangkan faktor yang lainnya tetap. Hasil dari uji $t$ dapat diperoleh nilai $t_{\text {hitung }}$ adalah 4,284 sedangkan $t_{\text {tabel }}$ sebesar 1,672, di lain pihak nilai Sig $_{\text {hit }}$ adalah 0,000 sedangkan $\operatorname{Sig}_{\text {prob }}$ 0,05. Hal ini berarti bahwa nilai $t_{\text {hitung }} \geq \mathrm{t}_{\text {tabel }}(4,284 \geq$ $1,672)$ atau $\operatorname{Sig}_{\text {hit }} \leq \operatorname{Sig}_{\text {prob }}(0,000 \leq 0,05)$. Atas dasar uji t tersebut dapat disimpulkan $\mathrm{H}_{0}$ ditolak, artinya berarti ada beda pengaruh status sosial ekonomi terhadap minat berwirausaha di Desa Jururejo Kecamatan Ngawi Kabupaten Ngawi.

\section{PENUTUP}

\section{Simpulan}

1. Status sosial ekonomi yang berada di Desa Jururejo Kecamatan Ngawi Kabupaten Ngawi adalah baik. Hal ini terbukti dari hasil deskriptif variabel status sosial ekonomi dengan jumlah data $(\mathrm{N})$ sebanyak 60 mempunyai deskripsi data sebagai berikut: (a) jumlah skor total sebesar 3373; (b) nilai rata-rata hitung (mean) sebesar
56,22; (c) median sebesar 57,00; (d) modus sebesar 57; (e) standar deviasi sebesar 6,702; (f) nilai minimum sebesar 40; (g) nilai maximum sebesar 68. Dari analisis deskriptif di atas dapat dikatakan status sosial ekonomi di Desa Jururejo Kecamatan Ngawi Kabupaten Ngawi baik, karena dari 60 warga hasil kuisioner yang diperoleh nilai rata-rata $\geq 56,22$ sebanyak 47 warga atau $78 \%$, sedangkan yang berada di bawah rata-rata 13 warga atau $22 \%$.

2. Minat berwirausaha di Desa Jururejo Kecamatan Ngawi Kabupaten Ngawi adalah baik. Hal ini terbukti dari hasil deskriptif variabel minat berwirausaha dengan jumlah data $(\mathrm{N})$ sebanyak 60 mempunyai deskripsi data sebagai berikut: (a) jumlah skor total sebesar 3331; (b) nilai rata-rata hitung (mean) sebesar 55,52; (c) median sebesar 56,50; (d) modus sebesar 52; (e) standar deviasi sebesar 6,990; (f) nilai minimum sebesar 44; (g) nilai maximum sebesar 73. Dari analisis deskriptif di atas dapat dikatakan minat berwirausaha di Desa Jururejo Kecamatan Ngawi Kabupaten Ngawi baik, karena dari 60 warga hasil kuisioner yang diperoleh nilai hasil rata-rata $\geq 55,52$ sebanyak 38 warga atau $63 \%$, sedangkan yang berada di bawah rata-rata sebanyak 22 warga atau $37 \%$.

3. Status sosial ekonomi berpengaruh terhadap minat berwirausaha di Desa Jururejo Kecamatan Ngawi Kabupaten Ngawi. Terbukti dari hasil analisis regresi yang memuat uji korelasi, uji $\mathrm{F}$, dan uji t. Dari hasil uji korelasi diperoleh hasil nilai $\mathrm{r}_{\text {hitung }}$ adalah 0,490 sedangkan $\mathrm{r}_{\text {tabel }} 0,254$, di lain pihak besarnya Sig $_{\text {hit }}$ adalah 0,000 sedangkan $\operatorname{Sig}_{\text {prob }} 0,05$. Hal ini berarti bahwa nilai $r_{\text {hitung }} \geq r_{\text {tabel }}(0,490 \geq 0,254)$ atau $\operatorname{Sig}_{\text {hit }} \leq \operatorname{Sig}_{\text {prob }}(0,000 \leq 0,05)$, artinya status sosial ekonomi mempunyai hubungan yang positif dengan minat berwirausaha di Desa Jururejo Kecamatan Ngawi Kabupaten Ngawi. Sedangkan dari hasil 
uji $\mathrm{F}$ diperoleh hasil nilai $\mathrm{F}_{\text {hitung }}$ adalah 18,356 sedangkan $\mathrm{F}_{\text {tabel }}$ sebesar 4,007, di lain pihak besarnya $\operatorname{Sig}_{\text {hit }}$ adalah 0,000 sedangkan $\mathrm{Sig}_{\text {prob }}$ 0,05. Hal ini berarti bahwa nilai $\mathrm{F}_{\text {hitung }} \geq \mathrm{F}_{\text {tabel }}(18,356 \geq 4,007)$ atau $\operatorname{Sig}_{\text {hit }} \leq \operatorname{Sig}_{\text {prob }}(0,000 \leq 0,05)$, artinya status sosial ekonomi mempunyai pengaruh terhadap minat berwirausaha di Desa Jururejo Kecamatan Ngawi Kabupaten Ngawi. Selanjutnya dari hasil uji t diperoleh hasil nilai $t_{\text {hitung }}$ adalah 4,284 sedangkan $\mathrm{t}_{\text {tabel }}$ sebesar 1,672, di lain pihak nilai $\mathrm{Sig}_{\text {hit }}$ adalah 0,000 sedangkan $\mathrm{Sig}_{\text {prob }}$ 0,05 . Hal ini berarti bahwa nilai $t_{\text {hitung }} \geq t_{\text {tabel }}$ $(4,284 \geq 1,672)$ atau $\operatorname{Sig}_{\text {hit }} \leq \operatorname{Sig}_{\text {prob }}(0,000 \leq$ $0,05)$, artinya status sosial ekonomi mempunyai beda pengaruh terhadap minat berwirausaha di Desa Jururejo Kecamatan Ngawi Kabupaten Ngawi.

\section{Saran}

Setelah melakukan penelitian ini, penulis mencoba untuk mengemukakan beberapa saran yang mungkin dapat bermanfaat bagi berbagai pihak. Adapun saran-saran penulis sebagai berikut:

\section{Bagi Masyarakat}

Selain status sosial ekonomi yang dimiliki oleh masyarakat, ada juga kemauan ataupun keinginan untuk melakukan kegiatan berwirausaha. Adanya kemauan untuk membaca majalah maupun koran serta mencari informasi yang berkaitan dengan kewirausahaan masyarakat akan menambah informasi tentang kegiatan berwirausaha.

2. Bagi Lembaga

Diharapkan lembaga yang berhubungan dengan ketenagakerjaan dapat memberikan pelatihan atau penyuluhan tentang kewirausahaan. Agar masyarakat tidak hanya mengandalkan pekerjaan yang ada dan dapat menciptakan lapangan kerja sendiri setelah diberikan penyuluhan kewirausahaan.
3. Bagi Peneliti Mendatang

Penelitian ini diharapkan dapat menambah wawasan serta dapat menerapkan kegiatan berwirausaha ini secara langsung dan ditekuni oleh peneliti lain di masa mendatang.

\section{DAFTAR PUSTAKA}

Buchari Alma. 2005. Kewirausahaan. Bandung: ALFABETA.

Burhan Bungin. 2006. Sosiologi Komunikasi. Jakarta: Prenada Media Group.

Dadang Supardan. 2008. Pengantar Ilmu Sosial. Jakarta: PT. Bumi Aksara.

Duwi Priyatno. 2010. Teknik Mudah dan Cepat Melakukan Analisis Data Penelitian SPSS. Yogjakarta: Gava Media.

Elizabeth B. Hurlock. 2003. Perkembangan Anak. Jakarta: PT. Gelora Aksara Pratama.

Husein Umar. 2011. Metode Penelitian Untuk Skripsi dan Tesis Bisnis. Jakarta: PT. Raja Grafindo Persada.

Juliansyah Noor. 2011. Metodelogi Penelitian. Jakarta: Prenada Media Group.

Leon Schiffman. 2004. Perilaku Konsumen. Jakarta: PT. INDEKS.

Moebarak.http://moebarak.wordpress. com/2011/12/05/minat-berwirausaha/ December 5, 2011

Mulyadi Nitisusasto. 2009. Kewirausahaan dan Manajemen Usaha Kecil. Bandung: ALFABETA.

Nana Syaodih Sukmadinata. 2005. Metode Penelitian Pendidikan. Bandung: PT. Remaja Rosdakarya.

Nugroho J. Setiadi. 2003. Perilaku Konsumen. Jakarta: Prenada Media. 
Panji Anoraga dan Djoko Sudantoko. 2002. Koperasi, Kewirausahaan, dan Usaha Kecil. Jakarta: PT. Rineka Cipta

Soerjono Soekanto. 2012. Sosiologi Suatu Pengantar. Jakarta: PT. Raja Grafindo Persada.

Sugiyono. 2009. Metode Penelitian Pendidikan. Bandung: Alfabeta. . 2010. Metode Penelitian Pendidikan. Bandung: Alfabeta.

Suharsimi Arikunto. 2010. Prosedur Penelitian. Jakarta: PT. Rineka Cipta.

Arikunto. 2012. Dasar-Dasar Evaluasi Pendidikan. Jakarta: Bumi Aksara.
Sukardi. 2003. Metode Penelitian Pendidikan. Jakarta: PT. Bumi Aksara.

Suryana. 2001. Kewirausahaan. Bandung: PT. Salemba Emban Patri.

Tim Penyusun Pedoman Penulisan Skripsi IKIP PGRI Madiun. 2013. Pedoman Penulisan Skripsi. Madiun: IKIP PGRI Madiun.

Uhar Suharsa Putra. 2012. Metode Penelitian. Bandung: PT. Refika Aditama.

Usman Rianse dan Abdi. 2012. Metodelogi Penelitian Sosial dan Ekonomi. Bandung: Alfabeta.

Yudrik Jahja. 2011. Psikologi Perkembangan. Jakarta: PRENADA MEDIA GROUP. 